\title{
Knowledge Risk Attitude Assessment Related To HIV/AIDS among BDS Students in Chennai, Tamil Nadu
}

\author{
Rajkumari S*, Murali Balasubramaniam A, Gauri Chandran S, Goutham Ranjith Nambiar and \\ Harinandhini K
}

Department of Oral Pathology and Microbiology, Satyabhama Dental College and Hospital, Chennai, TamilNadu, India

${ }^{*}$ Corresponding author: Rajkumari S, Department of Oral Pathology and Microbiology, Satyabhama Dental College and Hospital, Chennai, Tamil Nadu, India, Tel: +91-9840996439; E-mail: dr.rajkumari@yahoo.com

Received date: April 27, 2020; Accepted date: June 05, 2020; Published date: June 13, 2020

Citation: Rajkumari S, Murali Balasubramaniam A, Gauri Chandran S, Ranjith Nambiar G, Harinandhini K (2020) Knowledge Risk Attitude Assessment Related To HIV/AIDS among BDS Students in Chennai, Tamil Nadu. Arch Clin Microbiol Vol. 11 No. 3:111

Copyright: (C) 2020 Rajkumari S, et al. This is an open-access article distributed under the terms of the Creative Commons Attribution License, which permits unrestricted use, distribution, and reproduction in any medium, provided the original author and source are credited.

\section{Abstract}

Background: Acquired Immuno Deficiency Syndrome (AIDS) awareness is comparatively low in densely populated countries like India. India stands as the third largest country with HIV positive patients, with Tamil Nadu in the 6th position state wise. In this study a survey was conducted to assess the knowledge, attitude and risk related to AIDS among the undergraduate dental students in Chennai city, intended to create awareness among the youth thereby preventing the incidence of AIDS.

Method: A dichotomous self-administered questionnaire consisting of 16 questions was approved by Institutional Human Ethical Committee and it was distributed to 432 dental students in Chennai, the filled forms were later evaluated.

Result: This study reveals that the overall knowledge on AIDS among the study population was satisfactory. The knowledge on basics of AIDS is $84.12 \%$, cause of AIDS is $88.3 \%$, source of information about AIDS is $66.62 \%$ and knowledge on people at risk of developing AIDS is $79.72 \%$, while knowledge on prevention and management of AIDS is $88.12 \%$.

Conclusion: This study infers that overall knowledge about AIDS is better among the boys than the girls. Health education must be made mandatory at schools, colleges, community level to defend from the globally endangering disease.

Keywords: AIDS; Awareness; Chennai; Dental; HIV; Pandemic

\section{Introduction}

Acquired immunodeficiency Syndrome (AIDS) caused by Human Immunodeficiency Virus (HIV) is a modern pandemic that contributes to increased morbidity and mortality. The prevalence of HIV had increased rapidly since the first time it was first reported (1986) in India by Dr. Suniti Solomon. Government of India undertakes HIV estimations biennially in collaboration with the Indian Council of Medical Research (ICMR) - National Institute of Medical Statistics (NIMS) [1].

In 2010, 34 million people were reported with HIV globally. India is ranked 3rd in the world with largest population of HIV/ AIDS next to South Africa and Nigeria. Towards the end of 2017, the estimated population suffering with HIV in India was 21.40 lacs. The virus enters human body through unprotected sexual intercourse, sharing needles and contaminated blood transfusions. The virus may also infect the unborn fetus from an HIV infected mother called the Mother-To-Child Transmission and the newborn can acquire through breast milk [2]. Neither a cure nor a vaccine is available for AIDS [3,4].

Adolescence is a tantalizing period due to inadequate mental, physical, and social maturity they ought to seek pleasure from everything. AIDS is a disease which mainly spreads due to lack of orientation towards having multiple sexual partners and sharing of needles. About fifty percent of the new cases occur in individuals below 25 years of age [5]. The prevalence of the disease may differ in different parts of the country, to control this an overall awareness must be created. In this study we explored to assess the knowledge and awareness about AIDS among dental undergraduate students in Chennai, to educate them about the disease and its cause including the prevention and management.

\section{Methodology}

The study was conducted after obtaining Institutional Human Ethical Committee approval from Satyabhama Dental College and Hospital. A written informed consent was signed by all the participants. The study sample comprised of 432 
pupils including both the genders with 69 males and 363 females.

A dichotomous self-administered questionnaire consisting of 15 questions was formed to assess the knowledge and bring about awareness among the college going students in Chennai city. The questions were framed by modification of previous studies by various authors on similar topic [6-8], it was tested by a pilot study. The questionnaire was randomly distributed to the students of age range between 18 to 23 years. It consisted of four sections: (a) their socio-demographic data, (b) knowledge regarding AIDS, (c) attitude and (d) prevention and management of AIDS. The questionnaires were personally handed over to the students after explaining about the objective of the survey and were made sure that there was complete voluntary participation. The students were asked not to communicate with their peers in the process of filling the questionnaire and confidentiality was ensured.

\section{Results}

A total of 432 filled questionnaires were collected, and the answers were statistically assessed. About $80 \%$ of the study group were hostelries and the rest were day-scholars. All of them were from a good socio-economic background and were unmarried. All of them did not have habit of alcohol consumption or late-night partying with friends.

\section{Knowledge about HIV/AIDS}

All the boys were confident about the various sexually transmitted diseases (STDs), also there were able to differentiate between HIV and AIDS whereas only $95.7 \%$ of the girls were aware about the STDs and $24.28 \%$ thought that HIV and AIDS are same. There was confusion about the inheritance of AIDS as $12.5 \%$ of boys and $25.7 \%$ girls believed so.

The nature of the infection is still an enigma among $25 \%$ of boys and $14.28 \%$ of girls doubt if it is a viral infection. $93.75 \%$ boys and $95.7 \%$ girls believe AIDS is life threatening disease and exhibited similar response regarding the presentation of symptoms while $81.25 \%$ boys and 77.14 girls are aware that the AIDS affected person can look healthy. Six (12.5\%) of boys and $162(77.14 \%)$ girls believe that there exists a cure for the disease.

\section{Cause of AIDS}

Among various modes of infection sexual intercourse with an AIDS affected person ( $100 \%$ boys, $98.57 \%$ girls) injection with a needle used by AIDS/HIV positive ( $93.75 \%$ boys, $98.57 \%$ girls) transfusion of blood having AIDS virus (100\% boys, $98.57 \%$ girls) improperly sterilized syringes/needles at the hospital (100 boys, $97.14 \%$ girls) Mother to baby in the uterus is a possible ( $87.5 \%$ boys, $97.14 \%$ girls) are thought to be the predominant causative factor.

All of the male participants are sure (100\%) that living in the same house with an AIDS person, shaking hands with an AIDS person, drinking from a glass used by AIDS/HIV positive person, sharing the toiletries with an AIDS person does not contribute to the contraction of the infection whereas few girls still believe this in the order of 98\%, 98.58\%, 84.29\%, 93\% respectively for the same. One person from the male group believe that mosquito bite, kissing on the mouth with AIDS/HIV positive person, eating a meal prepared by AIDS or HIV person, sneezing and coughing are possible routes for infection cause AIDS while it is in the order of 2, 16, 5,11 out of 363 person from the female group agrees for the same. Some (31.25\% male, $20 \%$ female) still believe that tribal marks(tattooing) cause AIDS. Also $12.5 \%$ boys, $57.14 \%$ girls are unaware about the fact that if a HIV infected mother can feed her baby.

\section{Risk assessment}

Both the boys $(100 \%)$ and the girls $(100 \%)$ believe that, the major population at the risk of contracting the disease is mainly commercial sex workers, intravenous drug abusers (boys-87.5\%, girls-78.57\%) truck drivers (boys-68.75\%, girls-32.85\%), doctors from the patient (boys-25\%, girls-68.57\%). Some of the pupil (boys-25\%, girls-20\%) consider that professional blood donors can also acquire the disease. Both the study groups (100\%) are aware that faithful couples and regular office workers will never procure AIDS.

\section{Source of information}

Mass media serves as an efficient source of information for the study (boys-100\%), however the female group had a very less access to know about the AIDS. College syllabus $75.71 \%$, Newspaper magazine-62.85\%, School syllabus-55.71\%, teachers-54.28\%, TV,friends-34.28\%, parents-15.71\%, Radio, health professional-14.28\%, Video-2.85\% also contribute to the information regarding AIDS in lower percentage among the female group.

\section{Prevention and management}

All the pupil (100\%) were aware that there are tests to detect AIDS, however they believe (boys-18.75\%, girls-51.42\%) that vaccine is available for AIDS. The knowledge regarding the prevention of AIDS is as follows - all the male population $(100 \%)$ believe that sex education in curriculum, awareness programs, having single partner, safe blood transfusion, sterilization of needles and syringes, new blade at barber shop must be emphasized while the corresponding response from the female pupil is in the order of $97.14 \%, 95.71 \%, 87.14 \%$, $100 \%, 98.57 \%$, 90\% respectively.

Some (boys-93.75\%, girls-62.85\%) approve having multiple partners with the usage of condoms, avoiding pregnancy if infected with the AIDS virus (boys-87.5\%, girls-84.28\%). Few pupil (boys- $43.75 \%$, girls- $88.58 \%$ ) still believe that infected person must be outcast and isolated and eating nutritious food makes resistant to disease (boys-68.75\%, girls-87.15\%).

\section{Discussion}

AIDS virus - the HIV is thought to have originated from westcentral Africa and it was acquired by people involved in bush 
meat activities [9]. Later human to human spread occurred by sexual relationship with the infected person, reusage of syringe needles in mass vaccination programs [10-13]. The virus caused immune suppression in humans leading to multiple clinical presentation. Scientists are working on developing a cure, however it is not fully established

The awareness about AIDS must be incorporated in early stages of life which is a critical period, and there are chances of contracting the diseases due to ignorance. Hence the study conducted on college students targets the young people thereby indirectly educating them.

\section{Conclusion}

The knowledge on basics of AIDS (boys-89.84\%, girls-78.41), cause of AIDS (boys 91.66\%, girls-84.92\%), source of information about AIDS (boys-100\%, girls-33.24\%) was comparatively higher for boys than the girls. Both the genders have almost similar idea about the risky population (boys $79.46 \%$, girls $79.99 \%$ ) as well as prevention and management (boys-89.58\%, girls-86.66\%) of AIDS. Although overall data reveals that boys have better knowledge and awareness about AIDS than the girls like other studies mentioned above there is still lack of knowledge among the entire study group. Some pupil still believe that infected person must not be touched, and they must be outcast.

Though the educational curriculum involves most of the facts about AIDS, awareness programs must be mandatorily conducted at regular intervals to protect our society from the outrageous disease otherwise it may pose a threat to the global health.

\section{References}

1. India HIV Estimation 2017 Technical Report.

2. Nigeria FGO (2006) Federal Government of Nigeria. Prevention of mother to child transmission of HIV (PMTCT), in Trainers' manual, N. curriculum. Editor 2006, Federal Ministry of Health: Nigeria.

3. "About HIV/AIDS" (2015) CDC. December 6, 2015.

4. UNAIDS (2012) "The quest for an HIV vaccine".

5. Slesnick N, Prestopnik J (2005) Dual and Multiple Diagnosis Among Substance Using Runaway Youth. Am J Drug Alcohol Abuse 31: 179-201.

6. Rao S, Palani G, Harihara Iyer R, Sathiyasekaran BWC (2011) A Cross Sectional Study of HIV/Aids Awareness among College Students and Influence of Lifestyle, Sri Ramachandra Journal of Medicine 4: 5-10.

7. Madelene A, Louise A, Xiaodong T, Rune A (2009) HIV/AIDS Awareness, Attitudes and Risk Behavior Among University Students in Wuhan, China, The Open AIDS Journal 3: 55-62.

8. Maswanya E, Moji K, Aoyagi K, Yahata Y, Kusano Y, et al. (2000) Knowledge and Attitudes Toward AIDS Among Female College Students in Nagasaki, Japan, Health Education Research 15: 5-11.

9. Kalish ML, Wolfe ND, Ndongmo CB, McNicholl J, Robbins KE, et al. (2005) "Central African hunters exposed to simian immunodeficiency virus" Emerging Infectious Diseases 11: 1928-1930.

10. Marx PA, Alcabes PG, Drucker E (2001) "Serial human passage of simian immunodeficiency virus by unsterile injections and the emergence of epidemic human immunodeficiency virus in Africa" Philosophical Transactions of the Royal Society of London.Series B, Biological Sciences 356: 911-920.

11. de Sousa JD, Müller V, Lemey P, Vandamme AM (2010) Martin DP (ed.). "High GUD incidence in the early 20 centuries created a particularly permissive time window for the origin and initial spread of epidemic HIV strains" PLOS One 5: e9936.

12. Chitnis A, Rawls D, Moore J (2000) "Origin of HIV type 1 in colonial French Equatorial Africa? AIDS Research and Human Retroviruses 16: 5-8.

13. Donald G, McNeil J (2010) "Precursor to H.I.V. Was in Monkeys for Millennia". New York Times. 